\title{
Penerapan Sparse Principal Component Analysis dalam Menghasilkan Matriks Loading yang Sparse
}

\author{
Retno Mayapada ${ }^{*}$, Georgina M. Tinungki ${ }^{1}$, Nurtiti Sunusi ${ }^{2}$
}

\begin{abstract}
Sparse Principal Component Analysis (Sparse PCA) is one of the development of PCA. Sparse PCA modifies new variables as a linier combination of $p$ old variables (original variable) which is yielded by PCA method. Modifying new variables is conducted by producing a loading yang sparse matrix, such that old variable which is not effective (value of loading is zero) able be exit from PCA. In this study, Sparse PCA method was applied on data of Indonesia Poverty population in 2015, that contains 13 variables and 34 observation with variable reduction such that yields 4 (four) new variables, which can explain $80.1 \%$ of total variance data. This study show, the loading matrix that has been yielded by using Sparse PCA method to become sparse with there exist 11 elements (loading value) zero entry of matrix, such that the model that has been produced to be simpler and easy to be interpreted.
\end{abstract}

Keywords: Principal Component Analysis, Sparse Principal Component Analysis, reduksi dimensi, matriks loading yang sparse

\begin{abstract}
Abstrak
Sparse Principal Component Analysis (Sparse PCA) merupakan salah satu pengembangan dari metode PCA. Sparse PCA memodifikasi variabel-variabel baru yang merupakan kombinasi linear dari $p$ variabel lama (variabel asli) yang dihasilkan oleh metode PCA. Pemodifikasian variabel baru ini dilakukan dengan dengan menghasilkan matriks loading yang sparse sehingga variabel lama yang tidak efektif (memiliki nilai loading sama dengan nol) dapat dikeluarkan dari model PCA. Pada penelitian ini, metode Sparse PCA diterapkan pada data Indikator Kemiskinan Penduduk Indonesia Tahun 2015 yang memuat 13 variabel dan 34 observasi dengan reduksi variabel menghasilkan 4 (empat) variabel baru yang telah mampu menjelaskan $80,1 \%$ dari total variansi data. Hasil penelitian menunjukkan, matriks loading yang dihasilkan menggunakan metode Sparse PCA menjadi sparse dengan terdapat 11 elemen (nilai loading) matriks bernilai nol sehingga model yang dihasilkan menjadi lebih sederhana dan mudah untuk diinterpretasikan.
\end{abstract}

Kata Kunci: Principal Component Analysis, Sparse Principal Component Analysis, reduksi dimensi, matriks loading yang sparse

\section{Pendahuluan}

Principal Component Analysis (PCA) atau Analisis Komponen Utama (AKU) pertama kali diperkenalkan oleh Karl Pearson pada tahun 1901. PCA digunakan untuk menghitung kombinasi linier dan variabel baru yang menggambarkan keragaman data asli sebanyak mungkin, dengan dimensi matriks data asli dapat disederhanakan tanpa harus kehilangan informasi penting (Setyaningsih et al., 2010). Hingga saat ini, PCA telah banyak digunakan dalam berbagai bidang penelitian.

Akan tetapi, terdapat kekurangan pada metode PCA yaitu setiap Principal Component (PC) atau Komponen Utama (KU) merupakan kombinasi linier dari semua $p$ variabel. Artinya, setiap KU merupakan kombinasi linier dari semua variabel dengan beban (nilai loading)

*Program Studi Statistika, Departemen Matematika, Fakultas Matematika dan Ilmu

Pengetahuan Alam, Universitas Hasanuddin

${ }^{1}$ ina_matematika@yahoo.co.id,ntitisanusi@gmail.com² 


\section{Retno Mayapada, Georgina M. Tinungki, Nurtiti Sunusi}

diberikan ke setiap variabel. Nilai loading yang dihasilkan ini biasanya tidak nol. Hal ini mengakibatkan hasil KU yang diperoleh akan sulit untuk diinterpretasikan.

Salah satu perkembangan metode PCA adalah Sparse Principal Component Analysis (Sparse PCA) yang dapat digunakan untuk mengatasi masalah ini [1]. Sparse PCA diperkenalkan oleh Zou et al. pada tahun 2004. Sparse PCA menggabungkan kekuatan PCA klasik, reduksi data, dan pemodelan sparseness, yang menghasilkan matriks loading yang sparse sehingga dapat mengeluarkan variabel yang tidak efektif dari model PCA yang memiliki nilai loading (bobot) sama dengan nol [1]. Oleh karena itu, Sparse PCA memiliki kelebihan dalam membuat interpretasi KU menjadi lebih mudah.

\section{Landasan Teori}

\subsection{Principal Component Analysis}

Secara aljabar, Principal Component Analysis (PCA) adalah kombinasi linear khusus dari $p$ variabel acak $X_{1}, X_{2}, \ldots, X_{P}$. Secara geometri, kombinasi linear ini menggambarkan pemilihan dari sistem koordinat yang diperoleh dengan merotasikan sistem awal dengan $X_{1}, X_{2}, \ldots, X_{P}$ sebagai sumbu koordinat. Sumbu baru merupakan arah dengan variabilitas maksimum dan memberikan struktur kovariansi yang lebih sederhana. Prosedur PCA pada dasarnya adalah bertujuan untuk menyederhanakan variabel yang diamati dengan cara menyusutkan (mereduksi) dimensinya. Hal ini dilakukan dengan cara menghilangkan korelasi diantara variabel prediktor melalui transformasi variabel prediktor asal ke variabel baru yang tidak berkorelasi sama sekali atau yang biasa disebut dengan KU.

Setelah beberapa komponen hasil PCA yang bebas multikolinearitas diperoleh, maka komponen-komponen tersebut menjadi variabel prediktor baru yang dapat diregresikan atau dianalisa pengaruhnya terhadap variabel respon $(Y)$ dengan menggunakan analisis regresi. Reduksi data pengamatan ke dalam beberapa set data menggunakan PCA dapat dilakukan sedemikian sehingga informasi dari semua data dapat diserap seoptimal mungkin. Oleh karena itu, PCA dapat dipandang sebagai transformasi dari $X_{1}, X_{2}, \ldots, X_{P}$ [2]. KU yang terbentuk dapat dituliskan sebagai kombinasi linier dari variabel-variabel asalnya dan vektor eigen $\boldsymbol{e}_{1}, \boldsymbol{e}_{2}, \ldots, \boldsymbol{e}_{\boldsymbol{P}}$ dari matriks kovarians yang bersesuaian dengan nilai-nilai eigen seperti pada persamaan (1) berikut.

$$
\mathrm{KU}_{j}=e_{1 j} X_{1}+e_{2 j} X_{2}+\cdots+e_{P j} X_{p}, j=1,2, \ldots p
$$

Penentuan jumlah KU yang terpilih dapat didasarkan pada 3 kriteria yaitu dengan melihat titik pada scree plot ketika kurva mulai landai, nilai eigen $>1$, dan keragaman kumulatif yang dapat dijelaskan oleh KU minimal 80\%.

\subsection{Nilai Loading}

Nilai loading adalah koefisien dari transformasi KU yang memberikan hasil yang tepat mengenai pengaruh variabel-variabel asli dari KU dan merupakan dasar yang bermanfaat untuk interpretasi. Nilai koefisien yang besar menerangkan loading yang tinggi dan ketika nilai koefisien mendekati nol, artinya KU tersebut memiliki loading yang rendah [3]. Variabel yang memiliki nilai loading tepat nol dapat dikeluarkan dari fungsi KU.

Matriks loading yang sparse adalah matriks loading yang elemen-elemen (nilai loading)nya banyak bernilai nol. Nilai loading memberikan indikasi variabel asli (lama) mana yang sangat penting atau mempengaruhi pembentukan KU sebagai variabel baru. Semakin tinggi nilai loading dari suatu variabel lama maka semakin besar pula pengaruhnya terhadap pembentukan variabel baru [4]. Sebaliknya, semakin rendah nilai loading dari suatu variabel 


\section{Retno Mayapada, Georgina M. Tinungki, Nurtiti Sunusi}

lama maka semakin kecil pula pengaruhnya terhadap pembentukan variabel baru. Salah satu metode estimasi nilai loading yaitu metode PCA.

Nilai loading juga merupakan nilai vektor eigen dari penduga matriks kovarians dari $\mathbf{X}$ [5]. Sehingga nilai loading yang diperoleh hasilnya sama dengan nilai vektor eigen. Nilai loading ini digunakan sebagai koefisien dari fungsi KUnya [6]. Jenis pengaruh suatu variabel berdasarkan nilai loadingnya adalah sebagai berikut [7].

$$
\begin{array}{lll}
- & 0-0.3 & \text { : Tidak berpengaruh } \\
- & >0.3-0.4 & \text { : Berpengaruh } \\
-\quad>0.4-0.5 & \text { : Berpengaruh, dianggap penting } \\
-\quad>0.5-1 & \text { : Berpengaruh signifikan }
\end{array}
$$

\subsection{Sparse Principal Component Analysis}

Salah satu bentuk pengembangan terbaru dari PCA adalah Sparse PCA. Sparse PCA menggabungkan kelebihan PCA klasik, reduksi data, dengan pemodelan sparseness, yang menghilangkan variabel yang tidak efektif dari model PCA dengan mengecilkan nilai loading dari variabel-variabel ini menjadi nol. Oleh karena itu, Sparse PCA memiliki kelebihan dalam membuat interpretasi KU menjadi lebih mudah.

Zou et al. (2004) memperkenalkan Sparse PCA menggunakan metode Elastic Net untuk menghasilkan KU yang dimodifikasi dari nilai-nilai loading yang sparse. PCA dapat diformulasikan sebagai masalah optimasi pada regresi, sehingga nilai-nilai loading dapat diperoleh dengan menerapkan batasan Elastic Net pada koefisien regresi $\beta$ [8]. Elastic Net merupakan suatu metode seleksi variabel dengan menggabungkan regresi ridge dan LASSO. Dengan kata lain, Elastic Net menggabungkan batasan $L_{1}$-norm dan $L_{2}$-norm kuadrat pada $\beta$.

Penggabungan dua batasan tersebut diharapkan dapat menyeimbangkan kelemahan dari masing-masing metode (ridge dan LASSO) dengan batasan $L_{1}$-norm menghasilkan model yang lebih sederhana karena terjadi penyusutan beberapa $\beta$ yang tepat nol, sedangkan batasan $L_{2^{-}}$ norm kuadrat menghasilkan model yang tidak menyeleksi variabel namun meningkatkan efek pengelompokan dan penyusutan $\beta$ [9]. Metode Sparse PCA dengan menempatkan batasan $L_{1^{-}}$ norm dan $L_{2}$-norm kuadrat ini dapat menghasilkan nilai-nilai loading yang sparse dan persentase varians yang lebih tinggi daripada metode Sparse PCA yang hanya menempatkan batasan $L_{l}$-norm.

\subsubsection{Pendekatan Sparse}

Perhatikan bahwa setiap KU merupakan kombinasi linier dari $p$ variabel, sehingga pembebanannya (nilai-nilai loading) dapat diperoleh dengan cara meregresikan KU pada $p$ variabel.

\section{Teorema 1 [12]}

Untuk setiap $i, \boldsymbol{W}_{\boldsymbol{i}}$ adalah KU ke-i. Misalkan $\mathbf{X}_{n \times p}(n>p)$ adalah matriks yang memiliki rank penuh (full-rank), $\ell$ suatu bilangan non-negatif dan penduga ridge $\hat{\beta}_{\text {ridge }}$ diberikan oleh persamaan (2) berikut,

$$
\widehat{\boldsymbol{\beta}}_{\text {ridge }}=\underset{\beta}{\arg \min }\left\{\left\|\boldsymbol{W}_{\boldsymbol{i}}-\mathbf{X} \boldsymbol{\beta}\right\|^{2}+\ell\|\boldsymbol{\beta}\|_{2}^{2}\right\}
$$

$\widehat{\boldsymbol{v}}$ diperoleh dengan menormalisasikan $\widehat{\boldsymbol{\beta}}_{\text {ridge }}, \widehat{\boldsymbol{v}}=\frac{\widehat{\boldsymbol{\beta}}_{\text {ridge }}}{\left\|\widehat{\boldsymbol{\beta}}_{\text {ridge }}\right\|}$, dengan $\widehat{\boldsymbol{v}}=\mathbf{v}_{\mathbf{j}}$

Teorema 1 menunjukkan hubungan antara PCA dan metode regresi. Peregresian KU pada variabel-variabel dibahas oleh Cadima dan Jolliffe pada tahun 1995. Cadima dan Jolliffe (1995) berfokus pada pendekatan KU dengan subset dari variabel $k$ [10]. Zou et al., (2004) 


\section{Retno Mayapada, Georgina M. Tinungki, Nurtiti Sunusi}

melakukan pendekatan KU menggunakan regresi ridge. Setelah normalisasi, koefisien saling bebas terhadap $\ell$. Oleh karena itu penalti regresi ridge dalam bentuk $L_{2}$-norm kuadrat tidak digunakan untuk melakukan penalisasi koefisien regresi, tetapi untuk memastikan rekonstruksi KU. berikut [11].

Selanjutnya, tambahkan $L_{1}$-norm ke persamaan (2) sehingga diperoleh persamaan (3)

$$
\widehat{\boldsymbol{\beta}}=\underset{\beta}{\arg \min _{\beta}}\left\{\left\|\boldsymbol{W}_{\boldsymbol{i}}-\mathbf{X} \boldsymbol{\beta}\right\|^{2}+\ell\|\boldsymbol{\beta}\|_{2}^{2}+\ell_{1}\|\boldsymbol{\beta}\|_{1}\right\}
$$

dan $\hat{\mathbf{v}}_{\mathbf{i}}=\frac{\widehat{\boldsymbol{\beta}}}{\|\widehat{\boldsymbol{\beta}}\|}$, merupakan penduga dari $\mathbf{v}_{\mathbf{i}}$ dan $\mathbf{X} \hat{\mathbf{v}}_{\mathbf{i}}$ adalah penduga KU ke-i. Persamaan (2.4) disebut sebagai persamaan naive elastic net [12] atau dengan kata lain, persamaan (2.4) adalah regularisasi naive elastic net yang merupakan kombinasi dari $L_{1}$-norm dan $L_{2}$-norm kuadrat.

Selanjutnya, Zou et al. (2006) menyusun suatu algoritma untuk meminimukan nilai loading yang dihasilkan metode Sparse PCA berdasarkan persamaan (3). Misal $\widehat{\mathbf{B}}=$ $\left[\widehat{\boldsymbol{\beta}}_{1}, \widehat{\boldsymbol{\beta}}_{2}, \ldots \widehat{\boldsymbol{\beta}}_{\boldsymbol{k}}\right]$ merupakan matriks berukuran $p \times k, p$ jumlah variabel prediktor dan $k$ jumlah $\mathrm{KU}$ yang terpilih, dan $\widehat{\boldsymbol{\beta}}_{\boldsymbol{j}}$ suatu vektor penduga naive elastic net, subtitusi $\boldsymbol{W}_{\boldsymbol{j}}=\mathbf{X} \boldsymbol{\alpha}_{\boldsymbol{j}}$ untuk setiap $j=1, \ldots k$, ke persamaan (3) sehingga diperoleh persamaan (4) [8].

$$
\begin{aligned}
& \widehat{\boldsymbol{\beta}}_{\boldsymbol{j}}=\underset{\beta_{j}}{\arg \min }\left\{\left\|\mathbf{X} \boldsymbol{\alpha}_{\boldsymbol{j}}-\mathbf{X} \boldsymbol{\beta}_{\boldsymbol{j}}\right\|^{2}+\ell\left\|\boldsymbol{\beta}_{\boldsymbol{j}}\right\|_{2}^{2}+\ell_{1, j}\left\|\boldsymbol{\beta}_{j}\right\|_{1}\right\} \\
& \widehat{\boldsymbol{\beta}}_{\boldsymbol{j}}=\underset{\beta_{j}}{\arg \min }\left\{\left(\boldsymbol{\alpha}_{\boldsymbol{j}}-\boldsymbol{\beta}_{\boldsymbol{j}}\right)^{\mathrm{T}}(\|\mathbf{X}\|\|\mathbf{X}\|)\left(\boldsymbol{\alpha}_{\boldsymbol{j}}-\boldsymbol{\beta}_{\boldsymbol{j}}\right)+\ell\left\|\boldsymbol{\beta}_{\boldsymbol{j}}\right\|_{2}^{2}+\ell_{1, j}\left\|\boldsymbol{\beta}_{j}\right\|_{1}\right\}
\end{aligned}
$$

dengan mensubtitusikan $\|\mathbf{X}\|=\sqrt{\mathbf{X}^{\mathbf{T}} \mathbf{X}}$, maka diperoleh persamaan (4).

$$
\widehat{\boldsymbol{\beta}}_{\boldsymbol{j}}=\underset{\beta_{j}}{\arg \min }\left\{\left(\boldsymbol{\alpha}_{\boldsymbol{j}}-\boldsymbol{\beta}_{\boldsymbol{j}}\right)^{\mathrm{T}} \mathbf{X}^{\mathrm{T}} \mathbf{X}\left(\boldsymbol{\alpha}_{\boldsymbol{j}}-\boldsymbol{\beta}_{\boldsymbol{j}}\right)+\ell\left\|\boldsymbol{\beta}_{\boldsymbol{j}}\right\|_{2}^{2}+\ell_{1, j}\left\|\boldsymbol{\beta}_{\boldsymbol{j}}\right\|_{1}\right\}
$$

dengan $\left\|\boldsymbol{\beta}_{j}\right\|_{2}^{2}=\sum_{i=1}^{p} \beta_{i j}^{2}$ dan $\left\|\boldsymbol{\beta}_{j}\right\|_{1}=\sum_{i=1}^{p}\left|\beta_{i j}\right|$.

Catatan:

$\ell$ digunakan untuk semua $k \mathrm{KU}$, sedangkan nilai $\ell_{1, j}$ dapat berbeda-beda untuk setiap $j=$ $1, \ldots k \mathrm{KU}[8]$.

\subsubsection{Pemilihan Parameter Tuning}

Pemilihan $\ell_{1, j}$ pada persamaan (4) dapat dilakukan dengan menggunakan Cross Validation $(\mathrm{CV})$. Nilai $\ell_{1, j}$ dipilih dengan memperhatikan nilai CV terkecil [9]. CV yang sebaiknya digunakan adalah 5-fold atau 10-fold karena memberikan dugaan sisaan prediksi yang mempunyai bias tinggi namun memberikan MSE kecil dan juga variansi yang lebih kecil [8]. Adapun untuk pemilihan $\ell$, ditentukan oleh peneliti (dapat mempertimbangkan prinsip parsimony). $\ell$ yang dipilih adalah $\ell$ yang menghasilkan model matriks loading yang sparse dan proporsi keragaman kumulatif yang dihasilkan $\geq 80 \%$.

\subsubsection{Algoritma General SPCA}

Algoritma untuk Sparse PCA pada data dengan $n>p$ yang disebut sebagai algoritma General SPCA untuk mereduksi dimensi data menggunakan penduga Naive Elastic Net yang akan diterapkan pada penelitian ini sebagai berikut [11].

1. Misalkan $\mathbf{A}$ berisikan $\mathbf{V}[, 1: k]$ merupakan nilai-nilai loading dari metode PCA

2. Diberikan $\mathbf{A}=\left[\boldsymbol{\alpha}_{1}, \ldots, \boldsymbol{\alpha}_{\boldsymbol{k}}\right]$, hitung persamaan penduga naive elastic net untuk $j=1,2, \ldots, k$ berikut. 


$$
\widehat{\boldsymbol{\beta}}_{\boldsymbol{j}}=\underset{\beta_{j}}{\arg \min }\left\{\left(\boldsymbol{\alpha}_{\boldsymbol{j}}-\boldsymbol{\beta}_{\boldsymbol{j}}\right)^{\mathrm{T}} \mathbf{X}^{\mathbf{T}} \mathbf{X}\left(\boldsymbol{\alpha}_{\boldsymbol{j}}-\boldsymbol{\beta}_{\boldsymbol{j}}\right)+\ell\left\|\boldsymbol{\beta}_{\boldsymbol{j}}\right\|_{2}^{2}+\ell_{1, j}\left\|\boldsymbol{\beta}_{j}\right\|_{1}\right\}
$$

3. Untuk setiap $\mathbf{B}=\left[\boldsymbol{\beta}_{1}, \ldots, \boldsymbol{\beta}_{\boldsymbol{k}}\right]$ yang diperoleh dari langkah 2 , hitung SVD dari $\mathbf{X}^{\mathbf{T}} \mathbf{X B}=$ $\mathbf{U D V}^{\mathbf{T}}$, lalu perbaharui $\mathbf{A}=\mathbf{U V}^{\mathbf{T}}$

4. Ulangi langkah 2-3 sampai $\beta$ konvergen

5. Lakukan normalisasi: $\hat{\mathbf{v}}_{\mathbf{j}}=\frac{\boldsymbol{\beta}_{j}}{\left\|\boldsymbol{\beta}_{j}\right\|} ; j=1, \ldots, k$

\section{Metode Sparse Principal Component Analysis}

Metode Sparse PCA pada paper ini akan digunakan untuk memodifikasi matriks loading menjadi sparse. Sebelum menerapkan metode Sparse PCA, terlebih dahulu data akan dihitung matriks korelasinya untuk melihat apakan data terjadi multikolinieritas atau tidak. PCA akan berguna jika data yang diolah merupakan data yang terjadi multikolinieritas. Selanjut, data distandarisasi untuk menghilangkan satuan sehingga variabel-variabel pada data layak untuk dibandingkan. Setelah data distandarisasi, data kemudian diolah menggunakan metode PCA berdasarkan matriks kovarians untuk menentukan jumlah KU yang terpilih yaitu sebanyak $k$ dan menghitung matriks loadingnya.

Selanjutnya, matriks loading yang dihasilkan menggunakan metode PCA akan dimodifikasi menjadi matriks loading yang sparse menggunakan metode Sparse PCA. Pemodifikasian ini dilakukan dengan menghitung penduga naive elastic net $\widehat{\boldsymbol{\beta}}_{\boldsymbol{j}}$ menggunakan algoritma General SPCA untuk masing-masing KU. Sehingga, $\widehat{\boldsymbol{\beta}}_{\boldsymbol{j}}$ merupakan vektor berukuran $p \times 1$ untuk $j=1,2, \ldots, k$ yang berisi nilai-nilai loading yang sparse.

\section{Hasil dan Pembahasan}

\subsection{Sumber Data}

Data yang digunakan pada penelitian ini adalah data sekunder yaitu data Indikator Kemiskinan Penduduk Indonesia Tahun 2015 yang diperoleh dari Badan Pusat Statistika pada situs http://www.bps.go.id yang terdiri atas 13 variabel dan 34 observasi [13]. Variabel yang digunakan dalam penelitian ini adalah sebagai berikut.

$X_{1}$ : Tingkat Partisipasi Angkatan Kerja (TPAK) (\%)

$X_{2}:$ Kepadatan Penduduk (Jiwa/ $\left./ \mathrm{km}^{2}\right)$

$X_{3}$ : Indeks Pembangunan Manusia (IPM)

$X_{4}$ : Jumlah Penduduk Berusia 15-44 Tahun yang Buta Huruf (\%)

$X_{5}$ : Jumlah Rumah Tangga yang Memiliki Sumber Penerangan Listrik (\%)

$X_{6}$ : Jumlah Rumah Tangga yang Memiliki Luas Hunian per kapita $\geq 7.2 \mathrm{~m}^{2}(\%)$

$X_{7}$ : Angka Harapan Hidup (Tahun)

$X_{8}$ : Jumlah Penduduk yang Mempunyai Keluhan Kesehatan Selama Sebulan Terakhir (\%)

$X_{9}$ : Jumlah Balita yang Pernah Mendapat Imunisasi Campak (\%)

$X_{10}$ : Jumlah Rumah Tangga yang Memiliki Fasilitas Tempat Buang Air Besar Sendiri (\%)

$X_{11}$ : Tingat Pengangguran Terbuka (\%)

$X_{12}$ : Pengeluaran Bahan Makanan per Kapita Sebulan (\%)

$X_{13}$ : Pengeluaran Bukan Bahan Makanan per Kapita Sebulan (\%)

\subsection{Matriks Korelasi}


Perhitungan matriks korelasi dilakukan dengan tujuan untuk mengetahui korelasi antar variabel karena pada PCA mensyaratkan bahwa diantara variabel-variabelnya terdapat korelasi. Matriks korelasi yang diperoleh menunjukkan bahwa terdapat beberapa pasang variabel dengan nilai korelasi sangat kuat yaitu variabel $X_{2}$ dengan variabel $X_{18}\left(\rho_{2,18}=0,771\right), X_{3}$ dengan variabel $X_{7} \quad\left(\rho_{3,7}=0,783\right)$, dan $X_{12}$ dengan variabel $X_{13}\left(\rho_{12,13}=0,757\right)$. Hal ini menunjukkan bahwa PCA dapat digunakan untuk mereduksi variabel-variabel yang saling berkorelasi.

\subsection{Penentuan Jumlah Komponen Utama yang Terbentuk menggunakan Principal Component Analysis}

Untuk menentukan jumlah KU yang terbentuk, terdapat 3 kriteria yang bisa digunakan yaitu dengan melihat scree plot, nilai eigen, dan keragaman kumulatif yang dapat dijelaskan oleh KU.

\section{Scree Plot}

Scree plot adalah plot antara nilai eigen dengan banyaknya KU yang terbentuk. Jumlah KU yang terbentuk dapat diketahui dengan memperhatikan patahan siku dari scree plot. Scree Plot data dengan metode PCA dapat dilihat pada Gambar 4.1.

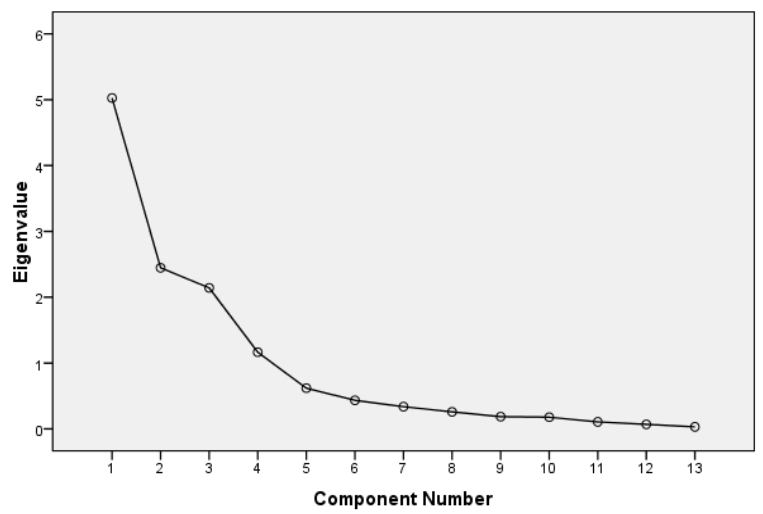

Gambar 1. Scree Plot data dengan metode PCA

Pada Gambar 1, terlihat bahwa kurva mulai meluruh setelah KU ke-4. Sehingga dapat disimpulkan bahwa jumlah KU yang terpilih adalah $4 \mathrm{KU}$.

\section{Nilai eigen}

KU yang terbentuk dapat ditentukan dengan memilih KU yang memiliki nilai eigen lebih besar dari 1. Nilai eigen dengan metode PCA disajikan dalam Tabel 1 dengan nilai eigen tiap KU telah terurut. Artinya KU pertama memiliki nilai eigen paling besar dan KU ke-tiga belas memiliki nilai eigen paling kecil.

Tabel 1. Nilai Eigen dengan Metode PCA

\begin{tabular}{cccc}
\hline KU ke- & Nilai Eigen & KU ke- & Nilai Eigen \\
\hline 1 & $\mathbf{5 . 0 2 5 5 6 2}$ & 8 & 0.259007 \\
\hline 2 & $\mathbf{2 . 4 4 6 7 9}$ & 9 & 0.18576 \\
\hline 3 & $\mathbf{2 . 1 4 1 9 9 8}$ & 10 & 0.177708 \\
\hline 4 & $\mathbf{1 . 1 6 4 8 9 2}$ & 11 & 0.106607 \\
\hline
\end{tabular}


Retno Mayapada, Georgina M. Tinungki, Nurtiti Sunusi

\begin{tabular}{llll}
\hline 5 & 0.619113 & 12 & 0.068969 \\
\hline 6 & 0.434757 & 13 & 0.031239 \\
\hline 7 & 0.337597 & & \\
\hline
\end{tabular}

Sumber: Data Diolah, 2018

Tabel 1 menunjukkan bahwa terdapat $4 \mathrm{KU}$ yang memiliki nilai eigen lebih besar dari 1 . $\mathrm{KU}_{1}$ memiliki nilai eigen sebesar 5.025562. Selanjutnya, $\mathrm{KU}_{2}$ memiliki nilai eigen sebesar 2.44679, $\mathrm{KU}_{3}$ memiliki nilai eigen sebesar 2.141998 dan $\mathrm{KU}_{4}$ memiliki nilai eigen sebesar 1.164892. Adapun $\mathrm{KU}_{5}$ hingga $\mathrm{KU}_{13}$ memiliki nilai eigen kurang dari 1. Sehingga dapat disimpulkan bahwa jumlah KU yang terbentuk menurut kriteria nilai eigen adalah $4 \mathrm{KU}$.

\section{Persentase Proporsi Keragaman Kumulatif}

KU yang terbentuk dapat ditentukan dengan memilih KU yang dapat menjelaskan proporsi keragaman data secara kumulatif minimal 80\%. Tabel 2 menunjukkan bahwa secara kumulatif, keempat KU pertama telah mampu menjelaskan $82.92 \%$ dari total variansi data. Sehingga, jumlah KU yang terbentuk menurut criteria ini adalah $4 \mathrm{KU}$.

Tabel 2. Proporsi Keragaman dan Keragaman Kumulatif dengan Metode PCA

\begin{tabular}{lll}
\hline $\begin{array}{l}\text { Komponen } \\
\text { Utama ke- }\end{array}$ & Proporsi keragaman & $\begin{array}{l}\text { Proporsi } \\
\text { keragaman kumulatif }\end{array}$ \\
\hline 1 & 0.3866 & $\mathbf{0 . 3 8 6 6}$ \\
\hline 2 & 0.1882 & $\mathbf{0 . 5 7 4 8}$ \\
\hline 3 & 0.1648 & $\mathbf{0 . 7 3 9 6}$ \\
\hline 5 & 0.0896 & $\mathbf{0 . 8 2 9 2}$ \\
\hline 6 & 0.0476 & 0.8768 \\
\hline 7 & 0.0334 & 0.9102 \\
\hline 8 & 0.0260 & 0.9362 \\
\hline 10 & 0.0199 & 0.9561 \\
\hline 11 & 0.0143 & 0.9704 \\
\hline 12 & 0.0137 & 0.9841 \\
\hline 13 & 0.0080 & 0.9923 \\
\hline
\end{tabular}

Sumber: Data Diolah, 2018

Jumlah KU yang dipilih adalah sebanyak empat (4) berdasarkan ketiga kriteria pemilihan jumlah KU yaitu scree plot, nilai eigen dan persentase keragaman kumulatif.

\subsection{Matriks Loading menggunakan Metode Principal Component Analysis}

Jumlah KU yang diperoleh berdasarkan scree plot, nilai eigen, dan persentase keragaman kumulatif adalah empat KU yang merupakan variabel baru. Nilai Loading pada Tabel 3 menjelaskan hubungan (korelasi) antara variabel lama dengan variabel baru yang dibentuk dengan metode PCA. Berdasarkan Tabel 3, nilai loading beberapa variabel tidak memiliki perbedaan yang signifikan sehingga sulit untuk menentukan variabel mana yang paling banyak menjelaskan tiap KU. Oleh karena itu, tahapan analisis yang digunakan untuk mengatasi masalah tersebut adalah dengan menerapkan metode sparse PCA yang memodifikasi matriks loading dari Tabel 3.

Tabel 3. Matriks Loading Menggunakan Metode PCA

\begin{tabular}{cllll}
\hline Variabel & $\mathrm{KU}_{1}$ & $\mathrm{KU}_{2}$ & $\mathrm{KU}_{3}$ & $\mathrm{KU}_{4}$ \\
\hline$X_{1}$ & -0.251 & 0.013 & -0.437 & 0.286 \\
\hline
\end{tabular}




\begin{tabular}{lllll}
\hline$X_{2}$ & 0.188 & 0.322 & -0.350 & -0.427 \\
\hline$X_{3}$ & 0.409 & 0.016 & -0.127 & -0.037 \\
\hline$X_{4}$ & -0.304 & 0.048 & -0.300 & 0.205 \\
\hline$X_{5}$ & 0.373 & -0.225 & 0.119 & -0.149 \\
\hline$X_{6}$ & -0.243 & 0.409 & -0.217 & -0.288 \\
\hline$X_{7}$ & 0.350 & -0.079 & -0.120 & 0.232 \\
\hline$X_{8}$ & 0.107 & -0.368 & -0.335 & -0.387 \\
\hline$X_{9}$ & 0.231 & -0.300 & -0.308 & 0.010 \\
\hline$X_{10}$ & 0.323 & 0.082 & -0.014 & 0.505 \\
\hline$X_{11}$ & 0.143 & 0.299 & 0.462 & -0.234 \\
\hline$X_{12}$ & 0.200 & 0.472 & -0.021 & 0.270 \\
\hline$X_{13}$ & 0.303 & 0.013 & -0.437 & 0.286 \\
\hline
\end{tabular}

Sumber: Data Diolah, 2018

\subsection{Pemilihan Parameter Tuning $\ell$ dan $\ell_{1, j}$}

Pemilihan model terbaik penduga Elastic Net pada metode Sparse PCA dapat menggunakan Cross Validation (CV) dengan memilih $\ell_{1, j}$ yang memiliki nilai $\mathrm{CV}$ terkecil. Pada penelitian ini, diuji beberapa nilai $\ell$ untuk mendapatkan model yang sederhana namun tetap mampu menjelaskan keragaman data asli minimal $80 \%$. Nilai $\ell$ yang digunakan pada penelitian ini adalah $\ell=4$. Sedangkan untuk $\ell_{1}$ pada model $\mathrm{KU}_{1}$ yang terpilih $0.363636, \ell_{1}$ pada model $\mathrm{KU}_{2}$ yang terpilih adalah $0.525253, \ell_{1}$ pada model $\mathrm{KU}_{3}$ yang terpilih adalah 0.8485 , dan $\ell_{1}$ pada model $\mathrm{KU}_{4}$ yang terpilih adalah 1 .

\subsection{Matriks Loading menggunakan Algoritma Sparse Principal Component Analysis}

Sparse PCA mengeluarkan variabel yang tidak efektif dari model PCA dengan mengecilkan nilai loading menjadi nol. Tabel 4 merupakan hasil dari matriks loading menggunakan algoritma Sparse PCA. Berdasarkankan Tabel 4, terdapat 11 nilai loading yang bernilai nol, sehingga terlihat bahwa matriks loading yang dihasilkan oleh metode Sparse PCA menjadi lebih sederhana. Peneliti lebih memilih model yang lebih sederhana karena dapat memberikan kemudahan dalam melihat hubungan antara KU yang terbentuk dengan variabel lama (variabel prediktor).

Berdasarkan Tabel 4 akan dibentuk $4 \mathrm{KU}$ sebagai kombinasi linier variabel-variabel asalnya yaitu sebagai berikut.

$$
\begin{aligned}
& K_{i}=\boldsymbol{v}^{\prime}{ }_{i} \boldsymbol{X}=v_{1 i} X_{1}+v_{2 i} X_{2}+\cdots+v_{p i} X_{p} \quad i=1,2,3 \\
\mathrm{KU}_{\mathbf{1}}=\boldsymbol{v}^{\prime}{ }_{\mathbf{1}} \boldsymbol{Z}= & 0.111 Z_{1}-0.238 Z_{2}-0.423 Z_{3}+0.215 Z_{4}-0.372 Z_{5}+0.220 Z_{6}-0.362 Z_{7} \\
& -0.302 Z_{8}-0.370 Z_{9}-0.249 Z_{10}+0.034 Z_{11}-0.063 Z_{12}-0.304 Z_{13} \\
\mathrm{KU}_{\mathbf{2}}=\boldsymbol{v}^{\prime}{ }_{\mathbf{2}} \boldsymbol{Z}= & -0.103 Z_{1}-0.470 Z_{2}-0.067 Z_{3}-0.091 Z_{4}+0.195 Z_{5}-0.468 Z_{6}+0.184 Z_{8} \\
& +0.147 Z_{9}-0.055 Z_{10}-0.134 Z_{11}-0.454 Z_{12}+0.464 Z_{13} \\
\mathrm{KU}_{3}=\boldsymbol{v}^{\prime}{ }_{3} \boldsymbol{Z}= & 0.555 Z_{1}+0.424 Z_{4}-0.207 Z_{5}+0.081 Z_{7}+0.153 Z_{8}+0.256 Z_{9}+0.080 Z_{10} \\
& -0.606 Z_{11} \\
\mathrm{KU}_{\mathbf{4}}=\boldsymbol{v}^{\prime}{ }_{\mathbf{4}} \boldsymbol{Z}= & 0.376 Z_{2}+0.278 Z_{6}-0.211 Z_{7}+0.525 Z_{8}+0.080 Z_{9}-0.555 Z_{10}-0.009 Z_{11} \\
& -0.383 Z_{12}
\end{aligned}
$$

Tabel 4 Matriks Loading menggunakan Metode Sparse PCA

\begin{tabular}{crrrrr}
\hline Variabel & $\mathrm{KU}_{1}$ & $\mathrm{KU}_{2}$ & $\mathrm{KU}_{3}$ & \multicolumn{2}{c}{$\mathrm{KU}_{4}$} \\
\hline$X_{1}$ & 0.111 & -0.103 & & 0.555 & 0 \\
\hline
\end{tabular}


Retno Mayapada, Georgina M. Tinungki, Nurtiti Sunusi

\begin{tabular}{rrrrr}
\hline$X_{2}$ & -0.238 & -0.470 & 0 & 0.376 \\
\hline$X_{3}$ & -0.423 & -0.067 & 0 & 0 \\
\hline$X_{4}$ & 0.215 & -0.091 & 0.424 & 0 \\
\hline$X_{5}$ & -0.372 & 0.195 & -0.207 & 0 \\
\hline$X_{6}$ & 0.220 & -0.468 & 0 & 0.278 \\
\hline$X_{7}$ & -0.362 & 0 & 0.081 & -0.211 \\
\hline$X_{8}$ & -0.302 & 0.184 & 0.153 & 0.525 \\
\hline$X_{9}$ & -0.370 & 0.147 & 0.256 & 0.080 \\
\hline$X_{10}$ & -0.249 & -0.055 & 0.080 & -0.555 \\
\hline$X_{11}$ & 0.034 & -0.134 & -0.606 & -0.009 \\
\hline$X_{12}$ & -0.063 & -0.454 & 0 & -0.383 \\
\hline$X_{13}$ & -0.304 & -0.464 & 0 & 0 \\
\hline
\end{tabular}

Sumber: Data diolah, 2018

Tabel 5 Pengelompokkan Variabel Lama, dan Variansi yang dijelaskan Tiap KU Menggunakan Sparse PCA

\begin{tabular}{|c|c|c|}
\hline $\begin{array}{l}\text { Komponen } \\
\text { Utama }\end{array}$ & Variabel Lama & $\begin{array}{c}\text { Variansi } \\
\text { yang } \\
\text { dijelaskan }\end{array}$ \\
\hline \multirow[b]{2}{*}{$\mathrm{KU}_{1}$} & $\operatorname{IPM}\left(\mathrm{X}_{3}\right)$ & \multirow[b]{2}{*}{$35.7 \%$} \\
\hline & $\begin{array}{c}\text { Listrik }\left(\mathrm{X}_{5}\right) \\
\mathrm{AH}\left(\mathrm{X}_{7}\right) \\
\text { Imunisasi }\left(\mathrm{X}_{9}\right)\end{array}$ & \\
\hline & Kepadatan $\left(\mathrm{X}_{2}\right)$ & \multirow[b]{2}{*}{$18.5 \%$} \\
\hline $\mathrm{KU}_{2}$ & $\begin{array}{c}\text { Luas Hunian }\left(\mathrm{X}_{6}\right) \\
\text { Pengeluaran Makanan }\left(\mathrm{X}_{12}\right) \\
\text { Pengeluaran Non Makanan } \\
\left(\mathrm{X}_{13}\right) \\
\end{array}$ & \\
\hline & $\operatorname{TPAK}\left(\mathrm{X}_{1}\right)$ & \\
\hline $\mathrm{KU}_{3}$ & $\begin{array}{c}\text { Buta Huruf }\left(\mathrm{X}_{4}\right) \\
\text { TPT }\left(\mathrm{X}_{11}\right) \\
\end{array}$ & $16.0 \%$ \\
\hline $\mathrm{KU}_{4}$ & $\begin{array}{c}\text { Keluhan Kesehatan }\left(X_{8}\right) \\
\text { TBAB Sendiri }\left(X_{10}\right)\end{array}$ & $9.9 \%$ \\
\hline
\end{tabular}

Sumber: Data diolah, 2018

Pada Tabel 5 diketahui bahwa $\mathrm{KU}_{1}$ memiliki nilai persentase varian sebesar $35.7 \%$. Variabel yang paling banyak membentuk $\mathrm{KU}_{\mathbf{1}}$ yaitu variabel IPM, Listrik, Angka Harapan Hidup, dan Imunisasi $\mathrm{KU}_{\mathbf{1}}$ memiliki variansi paling besar diantara $\mathrm{KU}$ yang terbentuk lainnya, sehingga dapat dikatakan bahwa jumlahan dari variabel IPM, Listrik, Angka Harapan Hidup, dan Imunisasi menghasilkan variansi yang besar. $\mathrm{KU}_{2}$ dapat menjelaskan $18.5 \%$ dari total varians. Variabel yang paling banyak membentuk $\mathrm{KU}_{2}$ adalah Kepadatan, Luas Hunian, Pengeluran Makanan, dan Pengleuaran Non Makanan. Selanjutnya $\mathrm{KU}_{3}$ mampu menjelaskan variansi sebesar $16,0 \%$ dan variabel yang paing banyak membentuk $\mathrm{KU}_{3}$ yaitu TPAK, Buta Huruf, dan TPT. Selanjutnya $\mathrm{KU}_{4}$ mampu menjelaskan variansi sebesar 9,9\% dan variabel yang paling banyak membentuk $\mathrm{KU}_{4}$ yaitu Keluhan Kesehatan dan TBAB Sendiri. 


\section{Retno Mayapada, Georgina M. Tinungki, Nurtiti Sunusi}

\subsection{Penentuan Model Terbaik}

Hasil analisis dari metode PCA dan Sparse PCA dapat dilanjutkan ke tahapan regresi untuk melihat metode mana yang dapat menghasilkan model yang lebih baik. Pada penelitian ini, skor komponen utama yang dibentuk dari matriks loading diregresikan dengan variabel respon. Variabel respon yang digunakan adalah variabel Garis Kemiskinan. Adapun indikator yang digunakan untuk menentukan model terbaik adalah nilai AIC dan Koefisien Determinasi $\left(R^{2}\right)$. Nilai $R^{2}$ dan nilai AIC dari Model regresi menggunakan Metode PCA dan Sparse PCA dapat dilihat pada Tabel 7.

Tabel 7 Nilai $R^{2}$ dan nilai AIC dari Model Regresi menggunakan Metode PCA dan Sparse PCA

\begin{tabular}{clcc}
\hline No & Jenis Metode & $R^{2}$ & AIC \\
\hline 1 & PCA & $55.83 \%$ & 884.797 \\
\hline 2 & Sparse PCA & $56.25 \%$ & 884.475 \\
\hline
\end{tabular}

Sumber: Data diolah, 2018

Model terbaik berdasarkan indikator $R^{2}$ dan AIC adalah model yang memiliki nilai AIC terkecil dan nilai $R^{2}$ terbesar. Tabel 4.7 menunjukkan model yang diperoleh dari matriks loading yang sparse menggunakan metode Sparse PCA lebih baik daripada model regresi yang dihasilkan dari skor KU berdasarkan matriks loading tanpa modifikasi dari metode PCA karena mampu menghasilkan model regresi dengan nilai AIC lebih kecil dan nilai $R^{2}$ yang lebih besar.

\section{Kesimpulan}

Berdasarkan pembahasan, diperoleh kesimpulan bahwa matriks loading dari hasil reduksi variabel pada data Indikator Kemiskinan Penduduk Indonesia Tahun 2015 yang berjumlah 13 (tiga belas) variabel menjadi 4 (empat) KU lebih sederhana dan sparse setelah dimodifikasi menggunakan metode Sparse PCA. Model KU yang telah dimodifikasi dari matriks loading menggunakan metode Sparse PCA menjadi lebih sederhana (sparse) dan mudah untuk diinterpretasikan dengan terdapat 11 nilai loading bernilai nol (41 nilai loading lainnya tidak bernilai nol). Secara kumulatif, ke-4 (empat) KU yang dibentuk dari matriks loading yang sparse telah mampu menjelaskan $80.1 \%$ variansi dari total data.

\section{Daftar Pustaka}

[1]. Hsu, Y. L., P. Y. Huang, dan D. T. Chen., 2014. Sparse Principal Component Analysis In Cancer Research. Transl Cancer Res. 3(3): 182-190.

[2]. Soemartini., 2012. Aplikasi Principal Component Analysis (PCA) dalam Mengatasi Multikoliniearitas Untuk Menentukan Investasi Di Indonesia Periode. 2001.1 - 2010.4. Bandung: Universitas Padjajaran.

[3]. Rachmatin, D., 2015. Aplikasi Metode Weighted Principal Component Analysis (WPCA) dengan Software S-PLUS2000. Jurnal Penelitian Sains UNSRI. 17(2): 51-58.

[4]. Sharma, S., 1996. Applied Multivariate Techniques. New York: John Wiley and Sons, Inc.

[5]. Varmuza, K. dan P. Filzmoser., 2009. Introduction to Multivariate Statistical Analysis in Chemometrics. Florida: CRC Press.

[6]. Tantular, B., 2011. Praktikum Analisis Data Multivariat II Menggunakan Software R: Modul 1 Analisis Komponen Utama. https://berthoveens.files.wordpress.com /2011/07/modul-multi.pdf dan bertho@unpad.ac.id. 20 Desember 2018(09:17). 
Retno Mayapada, Georgina M. Tinungki, Nurtiti Sunusi

[7]. Hair, J.F. Jr. , Anderson, R.E., Tatham, R.L., dan Black, W.C. 1998. Multivariate Data Analysis, (5 th. Edition). Upper Saddle River, NJ: Prentice Hall.

[8]. Zou, H., T. Hastie, dan R. Tibshirani. 2004 Sparse Principal Component Analysis. California: Department of Statistics, Stanford University.

[9]. Ramadhini, Fitri. 2014. Penyusutan Koefisien dan Seleksi Variabel Regresi dengan Elastic Net [skripsi]. Yogyakarta: UGM.

[10]. Cadima, J. F. dan I. T. Jolliffe, I. T. 1995. Loadings and Correlations in the interpretation of Principal Components. Journal of Applied Statistics. 22(2): 203-214.

[11]. Zou, H., T. Hastie, dan R. Tibshirani. 2006. Sparse Principal Component Analysis. Journal of Computational and Graphical Statistics. 15(2): 265-286.

[12]. Zou, H. dan T. Hastie. 2003. Regression Shrinkage And Selection Via The Elastic Net. California: Department of Statistics, Stanford University.

[13]. Badan Pusat Statistik. 2015. Data Indikiator Kemiskinan Penduduk Indonesia Tahun 2015 [ditemukan pada situs http://www.bps.go.id pada 13 Februari September 2018]. 